\section{F. W. J. Hemmings}

Theatre and State in France, 1760-1905

Cambridge: Cambridge University Press, 1994.

285p. $£ 37.50$ (hbk).

ISBN 0-521-45088-8

In this second book, which complements his earlier volume The Thentre Industry in NineteenthCentury France, Hemmings again offers an impressive and wide-ranging study which details how the material conditions of theatre are affected by state control and intervention. In a style which is both readable and scholarly, the study includes documentation of the working conditions of performers (with some illuminating detail on the imprisonment of actors and actresses); theatres, plays, and performances during the French revolution; the declining prosperity of provincial theatre in relation to the political and cultural hegemony of Paris; the licensing system (which, until its abolition in 1864, prevented women from managing theatres); the 'guerilla tactics' of audiences in subversive, political applications to the meanings of productions; the Parisian institution of the café-concert; and the role of dramatic censorship until its eventual abolition in 1905 .

The relations between state and theatre make this volume of interest to students of French theatre, history, and culture. The final chapter on 'the private sector', which looks out to the unofficial margins of the theatre industry (from the theatrical enterprises of Marie-Antoinette to the private performances of André Antoine), contains the germ of a future full-length study - the next Hemmings volume?

ELAINE ASTON

\section{A. M. Bowie \\ Aristophanes: Myth, Ritual, and Comedy Cambridge: Cambridge University Press, 1993. 328 p. $€ 40.00$. \\ ISBN 0-521-44012-2.}

This is an important work of scholarship, densely packed with details and insights that illuminate the religious and cultural contexts in which each of Aristophanes' comedies were first received. In its methodology, it follows the approach pioneered by figures such as Gernet, Vernant, and Vidal-Naquet. Throughout the work, Bowie's concern is to understand the plays from the point of view of the polis, and he is explicit from the outset that 'this book is concerned with audience reception rather than authorial intention'.

A chapter is devoted to each of the extant comedies. Thought-patterns and allusions, particularly to myths and rituals, are analyzed with care, and the extent to which they could have been brought into play through performance is emphasized. There is nothing reductive in Bowie's approach, and no unifying pattern or model is discerned or imposed. His purpose is 'to open up as many questions as possible' and, like the comedies he so richly interprets, he is 'not preaching but probing'.

LESLIE DU S. READ

Perry Gethner, ed.

The Lunatic Lover and Other Plays by French Women of the Seventeenth and Eighteenth Centuries.

Portsmouth: Heinemann, 1994. 344 p. ISBN 0-435-08637-5.

\section{Cecelia Beach}

French Women Playwrights before

the Twentieth Century: a Checklist

Westport, Conn.; London: Greenwood Press, 1994. 253 p. $€ 58.50$ (hbk).

ISBN 0-313-29174-8.

Cecelia Beach writes in her introduction that the most common reaction to hearing that her thesis was on French women playwrights was 'Are there any?' In France as elsewhere, women's work as playwrights has lagged behind that in novels, poetry, diaries, and other forms, in receiving the critical and bibliographic attention it deserves. Both these books are welcome additions which help to rectify this situation, and also open up the possibility of new productions.

The first original drama by women had appeared earlier in France than in Britain, where the earliest sixteenth-century playwrights like Mary Sidney and Joanna Lumley were translators from French and Greek. Beach lists the Theatre profane and the comedies of Marguerite de Navarre ( 1492-1549), whose plays, dating from 1535 onwards, are often completely forgotten by students of her famous story sequence, the Heptameron. She was followed by the mother and daughter Cathérine and Madeleine des Roches (from 1571), and by Cathérine de Rohan (from 1574) - and a case could be made to include (which Beach does not) earlier women who wrote dialogues such as Christine de Pisan in the fifteenth century or Louise Labé, whose Le Debat de folie d'amour dates from around 1550 .

In the period covered by Gethner, women ventured onto the male preserve of public stages, and some won applause, although they often found their successes attributed to male authors or labelled derivative. Gethner presents six diverse plays in lucid, highly readable translations, though, sadly, Marie-Anne du Boccage's ardently feminist Les Amazones is not among them - and Anne de la Roche-Guillen's comic ballet-opera, All-Wondrous (1677), written for the English court, is rather an odd choice, though it 